\title{
The Effect of Service Quality and Relational Efforts on Transaction Satisfaction, Relational Outcome and Customer Retention in Retail Business in the City of Banjarmasin
}

\author{
Noor Ritawaty \\ Student of Doctor of Economics Program. \\ Faculty of Economics and Business \\ University August 17, 1945 Surabaya \\ Ujianto \\ August 17, 1945 Surabaya University \\ Slamet Riyadi \\ August 17, 1945 Surabaya University
}

\begin{abstract}
The study aims to analyze the influence of the services quality and relational efforts relational satisfaction, relational outcomes and retention of customers in the retail business in the city of Banjarmasin. The population in this study is the consumer supermarket in the city of Banjarmasin, such as Hypermart, Giant. Lottemart, and Ramayana Robinson. Given the respondents in this study is homogeneous, so that the sample collection technique is systematic random sampling with selected respondents must meet predetermined criteria standards. because the population is not limited to, the proportional method used to determine the number of samples as many as 200 . Data analysis using SPSS and AMOS 20.0 software. From the test results that, only 7 hypothesis have a significant effect, namely: services Quality has significantly influence to customer satisfaction of retail transactions in Banjarmasin. Quality of service is a significant effect on the retention of retail customers in the city of Banjarmasin. Relational Efforts significant effect on satisfaction of customer transactions in Banjarmasin. Relational efforts has significant influence to outcome relational. Satisfaction transaction has significant influence to outcome relational retail customers in the city of Banjarmasin. Transactions Satisfaction has significant effect to the customer retention of retail customers in the city of Banjarmasin. Outcome relational has significant effect on the customersretention in the city of Banjarmasin. While two other hypothesis has not significant are: Quality of service not significant effect on relational outcomes retail customers in the city of Banjarmasin. Efforts relational no significant effect on the retention of retail customers in the city of Banjarmasin.
\end{abstract}

Keywords: Service Quality, Relational Effort, Transaction Satisfaction, Relational Outcomes, Customer Retention

\section{INTRODUCTION}

The retail business has existed since time immemorial, beginning with the traditional retail business. The onslaught of modern retailing is not this time, every decade a new format of modern retail emerges that shifts traditional retail. Many factors drive the success of largescale modern retail, some of which are the right location choice, information system technology support, low prices, and product completeness (Wijaya, 2002). Meanwhile, according to Meerzorg (2003) one of the keys to success in the field of modern retail business is the implementation of a customer relationship strategy, besides of course determining the location, pricing strategy and the use of information technology. This opinion is reinforced by 
Crosby et al (1990) by suggesting that in today's retail environment relationship marketing tactics play an important role in increasing consumer demands for building harmonious relationships between customers and retailers. The opinion of Sweeney cited in Suhata (2003) confirms that the implementation of relationship marketing strategies is indeed needed in the retail business. One of the implementation of relational strategies according to Levy and Weitz (2004) is communication of preferential treatment, personalization and rewarding which can be termed relational efforts. Retail business in the city of Banjarmasin in the last few years has experienced quite rapid development, this can be seen by the number of retailers both large and small scale already present, such as Hypermart, Lote Mart, Gian, Ramayana, Indomaret and Alfamart, which also spread the rampant trading. This is in line with developments in the distribution business, services and open market opportunities, as well as the encouragement of the government through regulations and legislation regarding retail businesses. One of the keys to success in a modern retail business is the implementation of a relationship marketing strategy, which is inseparable from determining the location, pricing strategy and the use of information technology (Meerzorg: 2003). This is confirmed by Crosby and Cowles (1990) who suggest that in today's retail environment, relationship strategies play an important role in increasing consumer demands for the building of harmonious relationships between customers and retailers.

Managing customer relationships is the central point of marketing discipline. Therefore, in addition to the need to build relationships, several studies indicate that the development of excellent service quality is needed by retailers to be able to survive in the competition. This statement is supported by Fulerton (2004), who argues that various studies of relational marketing show that customer commitment is a key factor in determining customer retention rates. While the quality of service as a driving factor for retention. Therefore it is very meaningful to combine the two fields of study, namely the study of service quality and the study of relational marketing. According to Oderkeken et al (2003) research conducted on relationship marketing is not possible without the knowledge or understanding of the core variables that concern the relationship is the existence of a potential interaction in the past or future for consumers. Although the results of several studies recognize that the importance of relational marketing practices and service quality, as stated by Anderson and Weitz, Ganesan that consumers' perceptions of relational outcomes that are well-built by retailers will have an impact on customer retention behavior, empirical evidence about this must still dug again in connection with the development of the retail business in Indonesia which is growing rapidly.

\section{LITERATURE REVIEW AND HYPOTESIS}

Marketing strategy is a management that is arranged to accelerate the solution of marketing problems and make strategic decisions. Marketing is a function that has the greatest contact with the external environment. Therefore marketing plays an important role in developing strategies. According to Tjiptono (2002: 43), marketing strategy is a plan to be followed by marketing managers. This action plan is based on an analysis of the situation and company goals and is a way to achieve these goals.

According to Rangkuti (2002: 26) service or service is the gift of an invisible performance or action from one party to another party. The definition of service quality according to Bitner, et al in Tasunar (2006: 44) is the overall impression of the customer towards the inferiority / superiority of the organization and the services offered. Meanwhile according to Lovelock and Wright (2007: 99) service quality is the expected level of excellence and control over the level of excellence to meet customer desires. 
In order to produce a quality service, the company is expected to be able to measure the service that has been provided to its customers through a service quality measurement scale, the SERVQUAL model has been developed in several service quality measurement models, including a Hierarchical Approach developed by Brady \& Cronin (Tjiptono \& Chandra, 2009 : 160, namely: (1) Interaction quality, namely the company's ability to interact with customers, which includes attitudes, behaviors and expertise of company employees.

The main objective of Relationship Marketing is to build and retain loyal customers who benefit the company. Relationship Marketing is a belief in it, a trust that is very trusted so that the commitment appears and this commitment is an important requirement in building a relationship. A strong relationship has three characteristics. First, Relationship is a long continuous process. In this case we can not make intimate communication but rather on the general nature. Second is commitment, a strong commitment if each party is willing to invest. Third, in Relatonship there is dependency. Good dependency is voluntary in nature. A condition where the customer feels the benefits of dependence is not because he was forced by another party.

Relationship Marketing is also related to Customer Relations, Customer Relations is the output of the Relationship Marketing concept, which has also come to the attention of many marketing practitioners. This means that the company has a continuous relationship both with consumers and elements related to marketing. Both distributors, suppliers, retailers or even with competing companies. Bennett R, Janet \& Cote Leonard (ANZMAC 2000) stated that in Relationship Marketing, communication, trust and commitment are important factors in achieving attitudes of customer loyalty.

Customer satisfaction is an evaluation of the whole post-purchase that can be perceived with feelings of pleasure or disappointment after comparing the performance of the product with several purchasing standards. Based on the theory of two factors from Herzberg, attractive quality where attractive quality focuses on the relationship between the objective performance of service attributes and job satisfaction on service attributes.

According to Tjiptono (2008: 87) there are six core concepts of how to measure customer satisfaction, namely: (1). Overall Consumer Satisfaction, (2). Dimensions of customer satisfaction, (3). Confirmation of hope, (4). Interest in Repurchase, (5). Willingness to recommend, (6). Consumer Dissatisfaction.

There are three basic considerations for the realization of relationship outcomes, namely: relationship satisfaction, trust, relationship commitment and buying behavior (Oderkerken et al., 2003). Odekerken's opinion al., Refers to the results of Gruen's (1995) research which states that in the relational outcome model with a business context aimed at customers there are two models namely psychological outcomes and behavioral outcomes. Relational satisfaction, trust and commitment are dimensions in psychological relationship outcomes. Gruen (1995) also argues that activities in implementing relational efforts or relational tactics and loyalty programs will drive the realization of relational outcomes with the dimensions of relational trust, commitment and satisfaction.

Customer retention can be defined as the tendency of customers in the future to stay together with or use the same service provider (Ranaweera, 2003). Then according to Raab \& Shylajan (2008), customer retention is the result of more dependence on customers in relation to service providers or products. Customer retention emphasizes the activities of marketers in retaining customers. According to Seth, et al. (1996) in Hasan (2009: 81), consumer retention 
is maintaining business relationships that occur between product or service providers with customers.

The hypothesis raised by researchers in this study are: (1). Service quality has a significant effect on customer transaction satisfaction (2). Service quality has a significant effect on the relational outcomes of retail customers. (3). Service quality has a significant effect on retail customer retention. (4). Relational efforts have a significant effect on customer transaction satisfaction. (5). Relational efforts have a significant effect on the relational outcomes of retail customers. (6). Relational efforts have a significant effect on retail customer retention. (7). Customer transaction satisfaction has a significant effect on the relational outcomes of retail customers. (8). Customer transaction satisfaction has a significant effect on retail customer retention. (9). Relational outcomes significantly influence retail customer retention

\section{RESEARCH METHODS}

The population in this study are: (1). Pelanngan supermarkets in the city of Banjarmasin, (2). Hypermart customer, Giant. Lottemart, and Ramayana Robinson, (3). In large-scale supermarkets with customers who are members of the membership, (4). At a mid-scale supermarket with customers who regularly shop. This study used a sample of 200 respondents with the Purposive method. The analysis technique used to answer the hypothesis in this study is to use a structural equation model (structural Equation Model or SEM) using the AMOS and SPSS programs

\section{ANALYSIS AND DISCUSSION}

The results of the calculation of the goodness of fit index values generated by the Modified model shows the goodness of fit model.

Goodness off Fit Index SEM Model

\begin{tabular}{|l|c|c|c|}
\hline Goodness of Fit Index & Cut off Value & Model Results & Information \\
\hline Probability Chi-Square & $\geq 0,05$ & 268,080 & Fit \\
\hline CMIN/DF & $\leq 0,20$ & 2,128 & Not Fit \\
\hline GFI & $\geq 0,90$ & 0,883 & Marginal Fit \\
\hline AGFI & $\geq 0,90$ & 0,841 & Marginal Fit \\
\hline CFI & $\geq 0,90$ & 0,924 & Fit \\
\hline TLI & $\geq 0,90$ & 0,908 & Fit \\
\hline RMSEA & $\leq 0,08$ & 0,075 & Fit \\
\hline
\end{tabular}

The calculation results show that the overall suitability of the model tests does not all provide an index in accordance with that recommended. To improve the model, modification is needed by considering the modification index value and adjusting to the theory used. The results of the model modification using the theory guidelines and modification index are presented in the following figure 


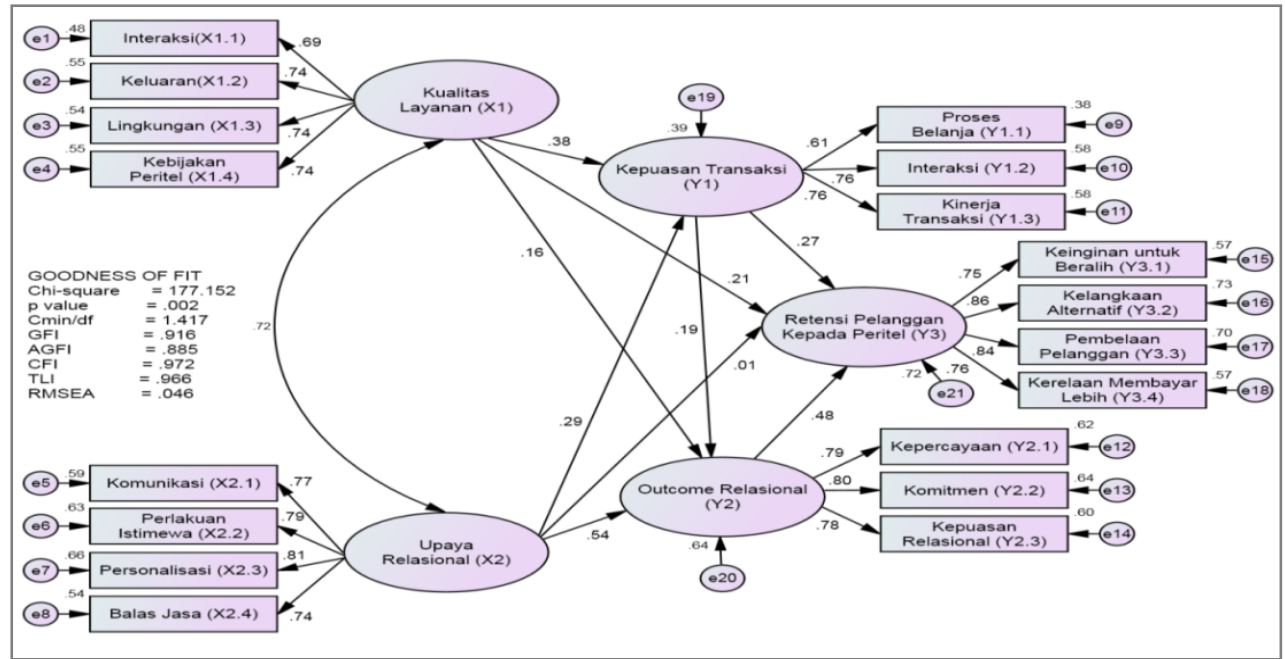

Image Of Full Structural Model

Testing the Structural Equation Hypothesis

\begin{tabular}{|c|c|c|c|c|c|}
\hline \multicolumn{3}{|c|}{ Causality Relations } & Estimate & $\begin{array}{c}\text { Critical } \\
\text { Ratio }\end{array}$ & P-Value \\
\hline $\begin{array}{l}\text { Quality of Service } \\
\text { (X1) }\end{array}$ & $\rightarrow$ & $\begin{array}{l}\text { Transaction Satisfaction } \\
\text { (Y1) }\end{array}$ & 0,376 & 2,734 & 0,006 \\
\hline $\begin{array}{l}\text { Quality of Service } \\
\text { (X1) }\end{array}$ & $\rightarrow$ & Relational Outcomes (Y2) & 0,164 & 1,445 & 0,148 \\
\hline $\begin{array}{l}\text { Quality of Service } \\
\text { (X1) }\end{array}$ & $\rightarrow$ & $\begin{array}{l}\text { Customer Retention to } \\
\text { Retailers (Y3) }\end{array}$ & 0,211 & 2,071 & 0,038 \\
\hline $\begin{array}{l}\text { Relational Efforts } \\
\text { (X2) }\end{array}$ & $\rightarrow$ & $\begin{array}{l}\text { Transaction Satisfaction } \\
\text { (Y1) }\end{array}$ & 0,294 & 2,200 & 0,028 \\
\hline $\begin{array}{l}\text { Relational Efforts } \\
\text { (X2) }\end{array}$ & $\rightarrow$ & Relational Outcomes (Y2) & 0,537 & 4,665 & 0,000 \\
\hline $\begin{array}{l}\text { Relational Efforts } \\
\text { (X2) }\end{array}$ & $\rightarrow$ & $\begin{array}{l}\text { Customer Retention to } \\
\text { Retailers (Y3) }\end{array}$ & 0,009 & 0,074 & 0,941 \\
\hline $\begin{array}{l}\text { Transaction } \\
\text { Satisfaction (Y1) }\end{array}$ & $\rightarrow$ & Relational Outcomes (Y2) & 0,194 & 2,104 & 0,035 \\
\hline $\begin{array}{l}\text { Transaction } \\
\text { Satisfaction (Y1) }\end{array}$ & $\rightarrow$ & $\begin{array}{l}\text { Customer Retention to } \\
\text { Retailers (Y3) }\end{array}$ & 0,272 & 3,074 & 0,002 \\
\hline $\begin{array}{l}\text { Relational Outcomes } \\
\text { (Y2) }\end{array}$ & $\rightarrow$ & $\begin{array}{l}\text { Customer Retention to } \\
\text { Retailers (Y3) }\end{array}$ & 0,483 & 4,086 & 0,000 \\
\hline
\end{tabular}

Based on the above table can be explained as follows:

1. Service quality variable significantly influences transaction satisfaction with a critical ratio of $2.734>1.96$ and p-value of $0.006<5 \%$, it can be concluded that there is a significant effect of service quality on transaction satisfaction. The results of this study are in line with the research of Andy Kurniawan (2010) which states that the attributes of quality of goods, prices, service friendliness, outlet cleanliness, convenience of outlets, payment facilities and parking facilities and security, are influential factors.

2. Service quality variables significantly influence the relational outcome with a critical ratio of $1.445<1.96$ and p-value of $0.148>5 \%$, it can be concluded that there is no significant effect of service quality on the relational outcome. The results of this study contradict the research proposed by Whidya C. Utami (2007) customer perceptions of service quality turned out to be able to contribute influence on the relational outcomes to retailers who carry out relational activities.

3. Service quality variable significantly influences customer retention to retailers with a critical ratio of $2.071>1.96$ and p-value of $0.038<5 \%$, so it can be concluded that there 
is a significant effect of service quality on customer retention of retailers. The results of this study are in line with the results of research by Whidya C Utami (2007). Which supports and reinforces the concept put forward by Zeithaml and Bitner (1999: 172174) that there are links and relationships between relational marketing, service quality and customer retention. The results of Fullerton's research (2004) also support the results of this study in which service quality is the main driver of customer retention.

4. The relational effort variable has a significant effect on transaction satisfaction with a critical ratio of $2,200>1.96$ and p-value of $0.28<5 \%$, so it can be concluded that there is a significant effect of the relational effort on transaction satisfaction. The results of this study are as stated by Odekerken et al (2003), which states that there is a significant and direct positive effect on transaction satisfaction, which can be concluded that building well relational activities will contribute significantly to customer transaction satisfaction

5. The relational effort variable has a significant effect on the relational outcome with a critical ratio of $4.665>1.96$ and a p-value of $0.000<5 \%$, so it can be concluded that there is a significant effect of the relational effort on the relational outcome. This study is in accordance with research conducted by Whidya C. Utami (2007) which states that relational efforts were able to contribute influence on relational outcomes to retailers through transaction satisfaction carrying out relational activities, as well as statements from Odekerken et al (2003) which also stated that building relationships becomes important as a foundation in building relational outcomes that are built from trust, commitment and relationship satisfaction in the long run.

6. The relational effort variable has a significant effect on customer retention to retailers with a critical ratio of $0.074<1.96$ and p-value of $0.941>5 \%$, so it can be concluded that there is no significant effect of relational efforts on customer retention of retailers. The results of this study contradict the statements of Odekerken et al (2003) and Whidya C Utami (2007) that there is a positive influence between relational efforts on customer retention of retailers. This means that customers have experienced changes in needs and desires, where not only the price, variety of goods and retail locations are important considerations for choosing retail, but rather the fulfillment of related desires and needs.

7. Transaction satisfaction variable significantly influences the relational outcome with a critical ratio of $2.104>1.96$ and p-value of $0.035<5 \%$, it can be concluded that there is a significant effect of transaction satisfaction on the relational outcome. The results of this study are supported by the opinion of Gruen (1995), that relational outcomes will be realized as a result of the implementation of relational efforts, while customer satisfaction acts as an intervening variable in the relationship of relational efforts towards relational outcomes.

8. Transaction satisfaction variable significantly influences customer retention to retailers with a critical ratio of $3.074>1.96$ and p-value of $0.002<5 \%$, it can be concluded that there is a significant effect of transaction satisfaction on customer retention of retailers. This study is in accordance with the opinion of Pierre Chanet et al (2000), that satisfaction in the context of overall satisfaction has a significant effect on customer retention.

9. The relational outcome variable has a significant effect on customer retention of retailers with a critical ratio of 4.086> 1.96 and a p-value of $0,000<5 \%$, so it can be concluded that there is a significant effect of the relational outcome on customer retention of retailers. This study is in accordance with the opinion of Fuilerton (2004) that the impact of relational marketing which can be interpreted as a relational outcome will build relationships not only relationships between customers and retailers, but build 
dependencies that can be manifested as the customer's desire to continue to choose one retailer or retention customers at certain retailers.

\section{SUMMARY}

1. The quality of retail services in the city of Banjarmasin can affect customer retention, both directly and indirectly through transaction satisfaction mediation, meaning retailers with good service quality, so customers tend to have good transaction satisfaction, so that it will have an impact on increasing retention retail customer.

2. Relational efforts of retail customers in Banjarmasin City do not directly influence customer retention, but indirectly through mediation of transaction satisfaction and relational outcomes, meaning that relational efforts made by retailers tend to satisfy customer transactions and produce good relational outcomes, too. so customer retention will increase. Improving the relational efforts of retailers can be done mainly by increasing personalization, that is, responding personally to customer complaints related to the quality of goods, when making payment transactions, cashiers give polite greetings, and pay serious attention to customer complaints.

3. Satisfaction of retail transactions in the city of Banjarmasin can affect customer retention, both directly and indirectly through mediating relational outcomes, meaning that retailers who can satisfy transactions with customers will produce high relational outcomes, and will have an impact on increasing customer retention. Increasing satisfaction of retail transactions can be done mainly by improving interaction between customers and retail employees.

4. Relational outcome of retail customers in the city of Banjarmasin can affect customer retention, meaning retailers who have a relational outcome to customers, tend to have customers with high retention. Improving retail relational outcomes can be done primarily by increasing and maintaining trust, namely providing good services, being able to trust relationships, and never providing disappointing services.

5. Service quality is more dominant in providing effects on transaction satisfaction, because it has the largest coefficient value, then customer retention and relational outcomes.

6. Relational effort is more dominant in providing effects on relational outcomes, because it has the greatest coefficient value, then transaction satisfaction and customer retention.

7. Service quality has a direct or indirect effect on customer retention through transaction satisfaction mediation, so it can be said that transaction satisfaction fully mediates the effect of service quality on retail customer retention in Banjarmasin.

8. Relational efforts influence only indirectly on customer retention through mediating relational outcomes, so it can be said that relational outcomes mediate partially (partial mediation) the effect of relational efforts on retail customer retention in Banjarmasin City.

9. Customer retention factors that are the result apparently still need to be examined carefully, especially an indication of the low willingness of customers to pay more. Customers will not shop at certain retailers if there is a price increase, and do not want to pay higher because there is a choice of retailers.

\section{LIMITATION}

The limitations of the results of this study, based on the results of the study after testing the hypothesis and analysis of the Effect of Service Quality and Relational Efforts on Transaction Satisfaction, Relational Outcome and Customer Retention in Retail Businesses in Banjarmasin, are as follows: 
1. Many independent variables and other intervening variables that can be used to influence customer retention have not been revealed in this study, so there is a need for other studies to complete it.

2. This research only focuses on large-scale retail in Banjarmasin, so that respondents are not represented in medium and small scale retailers

\section{BIBLIOGRAPHY}

Assauri, Sofyan, 2008, Marketing Management, First Edition, Eighth issue, Publisher: Raja Grafindo, Jakarta Bennett Rebekah, et. al. 2000. Trust, Commitment And Attitudinal Brand Loyalty: Key

Chan, Syafruddin. 2003. Relationship Marketing: Marketing Innovations That Make Knees Customers. Jakarta: Gramedia Main Library.

Cranage, D. 2004. Plan to do it Right: And Plan for Recovery. International Journal of Contemporary Hospitality Management. Vol. 16, No. 04, pp.210-219

Cram, Tony. 1994. The Power of Relationship Marketing, How To Keep Customers For Life. London: Pitman Publishing.

Crosby L., Evan K and Cowles D, 1990, Relationship Quality in Service Selling: an Interpersonal Influence Perspective Journal of Marketing, Vol. 54, pp 68 -81

Desatnick, Robert L., 1987. "Managing To Keep The Custimer: How To Achieve And Maintain Supperior Customer Service Through The Organization". Jossey-Bass Publiers

Fullerton Gordon, 2004, The Service Quality Loyalty Relationship in Retail Service, Does Comitment Matter? Journal of Retailing and Consumer Service Accepted April 6, 2004

Gruen T, 1995, The Outcomes Set of Relationship Marketing in Consumer Markets, International Business Review, Vol 4, No.4, pp 447-469

Kotler, Philip, And Gary Armstrong. 2008. Principles of Marketing 12th Edition Volume 1. Jakarta: Erlangga - , 2004. Marketing Management: Millennium Edition Volume 1 Jakarta: Prenhallindo.

,. \& Keller, Kevin Lane. (2006). Marketing Management. , New Jersey: Prentice Hall.

Levy M, And Weitz A Barton, 2004, Retail Management, Fifthion, New York, USA, Mc Graw Hill, Irwin

Lovelock, Christopher, Jochen Wirtz, and Jacky Mussry. 2011. Marketing Management Services Volume 2 Interpreting Deni Wulandari and Devri Barnadi Putera. Jakarta: Erlangga.

and Wright K, Lauren. 2007. Marketing Management Services. Jakarta: Index.

Lupiyoadi, Rambatdan A. Hamdani. 2001. Marketing Services Management. Jakarta: Salemba Empat.

McKenna, R. 1991. Relationship Marketing: Successful Strategies for the Age of the Customer. New York: AddisonWesley Publishing Company. 